\title{
ANALISIS PELAKSANAAN RETENSI REKAM MEDIS GUNA MENGHINDARI PENUMPUKAN REKAM MEDIS INAKTIF DI RS X
}

\author{
Indra Lesmana ${ }^{1}$, Mas Rinaldo ${ }^{2}$, Erix Gunawan ${ }^{3}$ \\ Politeknik Piksi Ganesha Bandung, Indonesia ${ }^{1,2,3}$ \\ indralesmanaag@gmail.com ${ }^{1}$, masrinaldo485@gmail.com² , erix.gunawan@piksi.ac.id ${ }^{3}$
}

Received: 11-08-2021

Revised : 16-11-2021

Accepted: 18-11-2021

\begin{abstract}
Abstrak
Latar Belakang: Pelaksanaan retensi berkas rekam medis berpedoman pada standar operasional prosedur tentang penyimpanan berkas rekam medis di ruang penyimpanan. Ruang penyimpanan (Filing) merupakan tempat berkas rekam medis rawat jalan, rawat inap dan gawat darurat disimpan dengan metode tertentu dan pelaksanaan retensi rekam medis.
\end{abstract}

Tujuan: Tujuan penelitian ini adalah mengidentifikasi pelaksanaan retensi berkas rekam medis di RS X.

Metode: Jenis penelitian yang digunakan dalam penelitian ini ialah Penelitian Kualitatif. Penelitian kualitatif digunakan untuk menganalisis pelaksanaan retensi berkas rekam medis. Metode pengambilan data yang digunakan dalam penelitian ini dengan cara observasi, wawancara dan dengan meminta data dibagian rekam medis.

Hasil: Hasil penelitian yang didapatkan bahwa pada pelaksanaan retensi, petugas melaksanakan retensi sebanyak 50-100 berkas rekam medis dalam waktu 1 (satu) hari dan dalam satu (1) bulan petugas melaksanakan retensi sebanyak 1500 berkas rekam medis yang telah diretensi. Petugas bertanggung jawab atas pelaksanaan retensi dan petugas juga memiliki tugas pokok selain melaksanakan retensi berkas rekam medis. Alat yang gunakan untuk melakukan retensi di RS X hanya menggunakan buku dan alat tulis, staples, yang dilakukan setiap hari oleh petugas retensi. Sampel data pada penelitian ini adalah 6 petugas filing di RS X.

Kesimpulan: Pelaksanaan retensi di RS X ada 6 petugas yang bertanggung jawab terhadap pelaksanaan retensi setiap hari dan petugas berhasil menyelesaikan 50-100 berkas yang telah diretensi dengan jumlah per bulannya 1500 berkas rekam medis yang telah diretensi, petugas bertanggung jawab atas pelaksanaan retensi dan petugas juga memiliki tugas pokok selain melaksanakan retensi berkas rekam medis.

Kata kunci: analisis, retensi, rekam medis inaktif.

\section{Abstract}

Background: The implementation of medical record file retention is guided by standard operating procedures regarding storing medical record files in the storage room. 


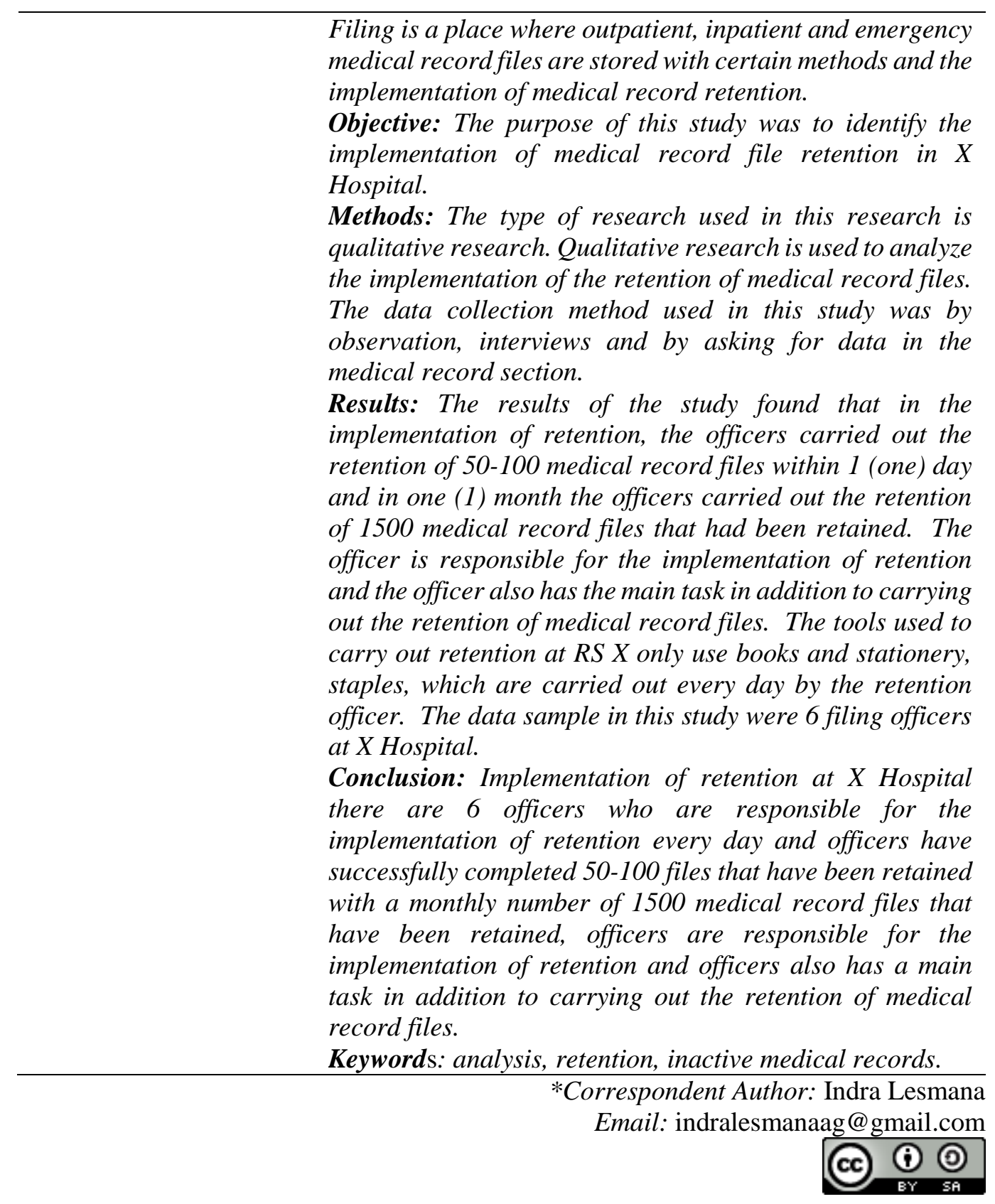

\section{PENDAHULUAN}

Rumah Sakit adalah institusi pelayanan kesehatan yang menyelenggarakan pelayanan kesehatan perorangan secara paripurna yang menyediakan pelayanan rawat jalan, rawat inap dan gawat darurat. Rumah Sakit sebagai institusi yang bergerak dibidang pelayanan kesehatan yang harus senantiasa memberikan kepuasan kepada setiap pasien dengan meningkatkan mutu dalam segala pelayanannya, dengan memberikan pelayanan kuratif dan rehabilitative (Permenkes, 2014).

Rekam Medis adalah berkas yang berisi catatan dan dokumen tentang identitas pasien, pemeriksaan, pengobatan, tindakan dan pelayanan lain kepada pasien pada fasilitas kesehatan (Menkes, 2013). Salah satu bagian rumah sakit yang menunjang dalam pelayanan rekam medis pasien adalah ruang penyimpanan (filing) dimana berkas rekam medis baik rawat jalan, rawat inap maupun gawat darurat disimpan karena rekam medis Analisis Pelaksanaan Retensi Rekam Medis Guna Menghindari Penumpukan Rekam Medis Inaktif di RS X 
pasien bersifat rahasia dan mempunyai aspek hukum maka keamanan fisik menjadi tanggung jawab rumah sakit, sedangkan aspek dari rekam medis merupakan milik pasien (Ritonga \& Wannara, 2020).

Pelaksanaan penyimpanan berkas rekam medis berpedoman pada standar operasional prosedur tentang penyimpanan berkas rekam medis di ruang penyimpanan.

Sebab hal itu, pemeliharaan dan pengawasan rekam medis dilakukan secara maksimal. Namun, penyelenggaraan dan pengelolaan rekam medis masih dilakukan sesuai dengan petunjuk buku (Salsabila, Syahidin, \& Hidayati, 2021). Ruang penyimpanan (filing) merupakan tempat berkas rekam medis rawat jalan, rawat inap dan gawat darurat disimpan dengan metode tertentu pelaksanaan retensi rekam medis (Wati \& Pujihastuti, 2011).

Retensi adalah proses memilih berkas rekam medis untuk memisahkan berkas rekam medis aktif ke inaktif sesuai jangka waktu penyimpanan berkas rekam medis. Dalam pelaksanaan retensi petugas melihat jadwal retensi arsip (JRA) sebagai pedoman untuk menentukan jangka waktu penyimpanan berkas rekam medis (Betri, 2020). Berkas rekam medis disimpan sekurang-kurangnya 5 tahun setelah dilihat dari terakhir pasien berobat. Pelaksanaan retensi bisa dilakukan setiap hari, setiap bulan maupun tahunan. Hal ini bertujuan untuk mengurangi jumlah berkas rekam medis yang ada dan untuk menghindari bertambahnya berkas rekam medis setiap harinya maka perlu adanya retensi berkas rekam medis (Latuconsina, Dewi, \& Susantyo, 2019).

Pelaksanaan retensi dengan cara memilih berkas rekam medis yang memiliki nilai guna seperti resume, informed consent, lembar operasi, lembar kematian dan lembar identitas bayi. Lembar yang memiliki nilai guna akan disimpan dan di scanner sedangkan berkas rekam medis yang tidak memiliki nilai guna akan ditumpuk diberkas rekam medis inaktif kemudian akan dilakukan pemusnahan rekam medis (Zulmi, 2016).

Permasalahan berdasarkan data yang peneliti temukan di RS X tersebut :

- $\quad$ Kekurangan tempat penyimpanan rekam medis (Filing)

- Tidak adanya Scanner

Berdasarkan survei awal pada tanggal 26 juli 2021 di Unit Rekam Medis RS X melalui wawancara Kepala Instalasi Rekam Medis bahwa RS X sudah melakukan retensi pada tahun 2020 kemarin. Data Kunjungan Pasien di RS X dari tahun 2016 sampai 2019 di RS X yang mengalami peningkatan jumlah kunjungan setiap tahun, sedangkan dari tahun 2020 terakhir mengalami penurunan jumlah kunjungan. Berdasarkan data kunjungan pasien dapat diketahui bahwa pada tahun 2016 sampai tahun 2017 mengalami peningkatan jumlah kunjungan sebanyak 17.605 pasien, tahun 2018 mengalami peningkatan jumlah kunjungan sebanyak 7.439 pasien, tahun 2019 mengalami peningkatan jumlah kunjungan sebanyak 6.354 pasien, dan tahun 2020 mengalami penurunan jumlah kunjungan sebanyak 36.271 pasien.

Tujuan Penelitian ini adalah Mengidentifikasi Pelaksanaan Retensi Berkas Rekam Medis Di RS X. Dapat diketahui bahwa terdapat jumlah kunjungan terendah pada tahun 2020 dan jumlah kunjungan tertinggi pada tahun 2019. Jumlah kunjungan setiap tahun mencapai rata-rata (Median) 205 pasien dan dapat menyebabkan rak penyimpanan aktif tidak bisa menampung berkas lagi jika tidak dilakukan retensi. Data kunjungan pasien dapat mempengaruhi penyimpanan rak berkas rekam medis aktif dimana hal ini sejalan dengan penelitian yang dilakukan oleh (Apriliani, Muflihatin, \& Muna, 2020) yang menyatakan bahwa data kunjungan dapat diketahui total pertambahan berkas rekam medis baru pertahun.

Berdasarkan hasil wawancara dengan petugas rekam medis di RS X, rekam medis tersebut disimpan di ruangan khusus dengan rak penyimpanan terbatas yang terbagi menjadi rak penyimpanan aktif dan rak penyimpanan inaktif. Berkas rekam medis tersebut tidak akan selamanya disimpan dirak penyimpanan aktif, karena akan terjadi penumpukan berkas rekam medis dirak tersebut. Rekam medis harus disimpan sesuai dengan peraturan yang telah dibuat sebelumnya yaitu masa simpan rekam medis dirak penyimpanan aktif di 
pelayanan selain rumah sakit maksimal dua tahun. Maka disediakan rak penyimpanan inaktif agar berkas rekam medis yang telah melewati batas maksimalnya dipindahkan ke rak tersebut sesuai peraturan yang berlaku.

Dengan adanya peraturan tersebut maka perlu adanya penyusutan berkas rekam medis atau biasa disebut retensi rekam medis. Menurut BPPRM (Buku Pedoman Penyelenggaraan Rekam Medis) tahun 2006, retensi memiliki pengertian yaitu suatu kegiatan memisahkan atau memindahkan antara dokumen rekam medis inaktif dengan dokumen rekam medis yang masih aktif di ruang penyimpanan (filing) (Gunawan, Nurseha, \& Hidayati, 2021). Retensi ini berguna untuk mengurangi jumlah formulir yang ada di dalam berkas rekam medis. Pengurangan dilakukan dengan cara menyortir satu persatu dan melihat berkas tersebut mempunyai nilai guna atau tidak. Jika memiliki nilai guna maka akan disimpan kembali dan jika tidak memiliki nilai guna maka akan dilanjutkan ke tahap selanjutnya. Penyusutan atau retensi di RS X bisa dilakukan sesuai dengan standar operasional prosedur yang ada di RS X. Penyusutan dilakukan untuk mengurangi penumpukan berkas rekam medis diruang penyimpanan agar rekam medis selalu tertata rapi dan rekam medis mudah ditemukan oleh petugas.

Berdasarkan latar belakang tersebut maka peneliti akan mengambil judul penelitian yaitu "Analisis Pelaksanaan Retensi Rekam Medis Guna Menghindari Penumpukan Rekam Medis Inaktif di RS X".

\section{METODE PENELITIAN}

Jenis penelitian yang digunakan dalam penelitian ini ialah Penelitian Kualitatif (Sugiyono, 2016). Penelitian kualitatif digunakan untuk menganalisis pelaksanaan retensi berkas rekam medis. Metode pengambilan data yang digunakan dalam penelitian ini dengan cara observasi, wawancara dan dengan meminta data dibagian rekam medis. Waktu pelaksanaan penelitian pada bulan mei-juli 2021 di RS X. Pada penelitian ini ialah 6 petugas rekam medis di bagian filing dan kepala instalasi rekam medis SOP retensi berkas rekam medis dan alat-alat retensi. Pengumpulan data dengan cara wawancara dan observasi, kemudian dianalisis sesuai teori.

\section{HASIL DAN PEMBAHASAN}

\section{A. Hasil Penelitian}

\section{Kebijakan Retensi Berkas Rekam Medis}

Berdasarkan hasil wawancara kepala instalasi rekam medis bahwa di RS X sudah memiliki standar operasional prosedur retensi rekam medis yang sesuai dengan SK Direktur No 180B/SK-Dir/XII/2018 tentang Kebijakan Pelayanan Rekam Medis. Standar operasional prosedur yang telah dibuat oleh RS X ini bertujuan sebagai acuan penerapan langkah-langkah untuk proses retensi dan pemusnahan rekam medis. SOP retensi rekam medis yang ada di RS X ialah:

a. Petugas memilah berkas rekam medis inaktif di rak penyimpanan berdasarkan tahun kunjungan.

b. Memindahkan berkas rekam medis inaktif dari rak file rekam medis aktif ke rak file inaktif.

c. Simpan berkas rekam medis inaktif selama 2 tahun.

d. Petugas melakukan penilaian selama 2 tahun.

Dari hasil wawancara yang dilakukan peneliti terhadap kepala instalasi rekam medis RS X pada tanggal 27 juli 2021 diketahui bahwa, RS X sudah melakukan retensi rekam 
medis dan pelaksanaan tersebut terkahir pada tahun 2020 yang lalu sebelum peneliti melaksanakan penelitian di RS X, dengan jumlah berkas rekam medis yang diretensi tidak dapat disebutkan oleh pihak RS X. Pada saat ini RS X melakukan retensi rekam medis terakhir pada tahun 2020 dengan jumlah berkas rekam medis 60.000 berkas yang akan diretensi. Jumlah tersebut hanya dari perkiraan peneliti dikarenakan kerahasiaan terkait berkas rekam medis.

Bagian berkas rekam medis yang tidak dapat diretensi tidak ada, hanya berpatokan yang sudah tidak aktif selama 2 tahun lamanya. Sehinga tidak terjadinya penumpukan di ruang penyimpanan berkas rekam medis. Karena retensi sudah dilakukan sebelum peneliti melakukan penelitian di RS tersebut. Sedangkan pada saat wawancara pemusnahan baru akan dilakukan pada bulan agustus mendatang, bulan tersebut peneliti sudah berakhir melakukan penelitian. Jadi peneliti tidak dapat menyaksikan saat pemusnahan. Pelaksanaan retensi yang dilakukan setiap 5 tahun sekali ini sesuai dengan SOP dan teori yang berlaku di RS X yang mengatur bahwa retensi dilakukan setiap 5 tahun dari kunjungan terkahir pasien. Alat yang gunakan untuk melakukan retensi di RS X hanya menggunakan buku dan alat tulis, staples, yang dilakukan setiap hari oleh petugas retensi. Walaupun tidak adanya kendala dalam proses retensi tetapi dianggap tidak efektif dan efisien dikarenakan tidak adanya alat scan untuk mengetahui nilai guna dalam berkas tersebut secara menyeluruh. Apabila tersedianya alat tersebut dapat menghemat waktu maupun memudahkan kinerja dibagian retensi.

1. Mengidentifikasi pelaksanaan retensi berkas rekam medis

Berdasarkan hasil wawancara yang dilakukan peneliti terhadap petugas rekam medis terkait jumlah keseluruhan berkas rekam medis dalam jangka waktu 1 tahun berjumlah 18.000 berkas rekam medis. Perhitungan tersebut sewaktu waktu bisa berubah dikarenakan target pelaporan dari SDM yang belum tentu tercapai. Tahap pelaksanaan retensi rekam medis dipisahkan dari rak aktif ke inaktif berdasarkan tanggal terakhir pasien datang untuk berobat, rekam medis diambil dari ruang filing aktif dipindahkan ke ruang inaktif dan disejajarkan. Dalam sistem penjajaran rekam medis inaktif menggunakan sistem penjajaran straight numerical system, disimpan di rak rekam medis inaktif dan ada juga yang disimpan di dalam kardus (Rustiyanto \& Rahayu, 2011). Guna ketentuan lamanya penyimpanan rekam medis inaktif berdasarkan wawancara dengan petugas filing RS X sekitar 2 sampai 3 tahun lamanya.

2. Tinjauan pelaksanaan retensi berkas rekam medis di RS X

Berdasarkan hasil wawancara yang dilakukan peneliti pada tanggal 27 juli 2021 pada petugas rekam medis terkait tinjauan pelaksanaan retensi berkas rekam medis. Jumlah petugas diruang filing secara keseluruhan ada 6 petugas rekam medis diantaranya 3 dibagian filing 3 petugas dibagian Instalasi Rekam Medis yang meliputi pelaporan, pengolahan data serta bagian Coding. Dikarenakan tidak adanya sccaner di RS tersebut hanya menggunakan buku dan alat tulis, staples, yang dilakukan setiap hari oleh petugas retensi, maka peneliti menyimpulkan bahwa pelaksanaan retensi tergolong lambat dan nilai guna tidak terdeteksi secara menyeluruh. Pada sistem penyimpanan rekam medis (ruang filing), terdiri dari 2 ruang penyimpanan berkas rekam medis, dalam ruang penyimpanan pertama terdapat 19 rak besi penyimpanan rekam medis aktif, sedangkan ruang penyimpanan kedua terdapat 47 rak besi penyimpanan rekam medis aktif dan terdapat 4 rak besi penyimpanan rekam medis inaktif dan Sistem penyimpanan secara sentralisasi.

\section{B. Pembahasan}

\section{Kebijakan Retensi Berkas Rekam Medis}


Berdasarkan hasil wawancara kepala instalasi rekam medis bahwa di RS X sudah memiliki standar operasional prosedur retensi rekam medis yang sesuai dengan SK Direktur No 180B/SK-Dir/XII/2018 tentang Kebijakan Pelayanan Rekam Medis. Standar operasional prosedur yang telah dibuat oleh RS X ini bertujuan sebagai acuan penerapan langkah-langkah untuk proses retensi dan pemusnahan rekam medis. SOP retensi rekam medis yang ada di RS X ialah :

1. Petugas memilah berkas rekam medis inaktif di rak penyimpanan berdasarkan tahun kunjungan.

2. Memindahkan berkas rekam medis inaktif dari rak file rekam medis aktif ke rak file inaktif.

3. Simpan berkas rekam medis inaktif selama 2 tahun.

4. Petugas melakukan penilaian selama 2 tahun.

Hal tersebut sudah sesuai dengan Permenkes RI No. 269/MENKES/PER/III/2008 pasal 9 tentang rekam medis yang menyatakan bahwa berkas rekam medis maksimal disimpan selama 2 tahun di rak aktif dan inaktif (Nomor, 2017).

1. Tinjauan pelaksanaan retensi berkas rekam medis di RS X

Berdasarkan hasil wawancara di RS X pada tanggal 27 juli 2021 bahwa RS X sudah melakukan retensi rekam medis dan pelaksanaan tersebut terkahir pada tahun 2020 yang lalu sebelum peneliti melaksanakan penelitian di RS X, dengan jumlah berkas rekam medis yang diretensi tidak dapat disebutkan oleh pihak RS X. Pada saat ini RS X melakukan retensi rekam medis terakhir pada tahun 2020 dengan jumlah berkas rekam medis 60.000 berkas yang akan diretensi. Jumlah tersebut hanya dari perkiraan peneliti dikarenakan kerahasiaan terkait berkas rekam medis.

Tahapan pelaksanaan retensi berkas rekam medis dipisahkan dari rak aktif ke inaktif berdasarkan tanggal terakhir pasien datang untuk berobat, rekam medis diambil dari ruang filing aktif kemudian dipindahkan ke ruang filing inaktif dan disejajarkan sesuai dengan sistem penjajaran straight numerical system. Untuk ketentuan lamanya penyimpanan berkas rekam medis inaktif berdasarkan wawancara dengan petugas filing RS X sekitar 2 tahun lamanya.

Petugas meretensi berkas rekam medis dalam waktu 1 (satu) bulan dengan jumlah 1500 berkas rekam medis dan seluruhnya dapat diretensi karena sudah memenuhi syarat dalam retensi. Untuk berkas rekam medis yang tidak dapat diretensi tidak ada, hanya berpatokan yang sudah tidak aktif selama 2 tahun lamanya. Sehinga tidak terjadinya penumpukan di ruang penyimpanan berkas rekam medis. Karena retensi sudah dilakukan sebelum peneliti melakukan penelitian di RS tersebut. Sedangkan pada saat wawancara pemusnahan baru akan dilakukan pada bulan agustus mendatang, bulan tersebut peneliti sudah berakhir melakukan penelitian. Jadi peneliti tidak dapat menyaksikan saat pemusnahan.

Pelaksanaan retensi yang dilakukan setiap 5 tahun sekali ini sesuai dengan SOP dan teori yang berlaku di RS X yang mengatur bahwa retensi dilakukan setiap 5 tahun dari kunjungan terkahir pasien. Hal tersebut sudah sesuai dengan Peraturan Menteri Kesehatan No. 269/MenKes/Per/III/2008 tentang rekam medis, Pasal 8 ayat (1): Rekam Medis Pasien Rawat Inap di rumah sakit wajib disimpan sekurangkurangnya untuk jangka waktu 5 Page 229 (lima) tahun terhitung dari tanggal terakhir

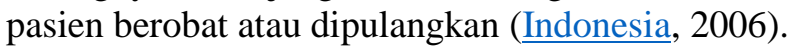

2. Menganalisis pelaksanaan retensi berkas rekam medis di RS X

Berdasarkan hasil wawancara pada tanggal 27 juli 2021 jumlah rekam medis yang di retensi tiap harinya mencapai $50-100$ berkas medis. Setiap bulan petugas meretensi berkas sebanyak 1500 berkas medis. Dalam ruang filing yang bertanggung jawab hanya 6 orang petugas dan itupun hanya unit terkait saja ialah petugas distribusi 
rekam medis dan petugas retensi rekam medis. Data Kunjungan Pasien di RS X yang dapat dilihat pada tabel 1, sebagai berikut:

Tabel 1. Data Kunjungan Pasien Tahun 2016 sampai 2020 di RS X

\begin{tabular}{ccc}
\hline No & Tahun & Jumlah Kunjungan \\
\hline 1 & 2016 & 59.574 \\
\hline 2 & 2017 & 77.179 \\
\hline 3 & 2018 & 84.618 \\
\hline 4 & 2019 & 90.972 \\
\hline 5 & 2020 & 54.701 \\
\hline
\end{tabular}

Sumber : Data sekunder bagian laporan, 2021.

Berdasarkan hasil pada tabel 1 di atas yang kami teliti selama 2 (dua) bulan data yang dihasilkan merupakan data hasil retensi selama 5 tahun terkahir ialah dari tahun 2016-2020. Dari hasil data selama 5 tahun tersebut peneliti menguraikan bahwa data kunjungan pasien pada [1] Tahun 2016 sebanyak 59.574 pasien, [2] Tahun 2017 sebanyak 77.179 pasien, [3] Tahun 2018 sebanyak 84.618 pasien, [4] Tahun 2019 sebanyak 90.972 pasien dan pada [5] Tahun 2020 sebanyak 54.701. Dari total data kunjungan pasien selama 5 tahun yaitu dari 2016-2020 data rekam medis yang telah dijumlahkan dan akan diretensi sebanyak 367.044 berkas rekam medis.

Menurut Permenkes nomor 269 MENKES/PER/III/2008 tentang Rekam Medis Bab III, pasal 7 bahwa lembaga pelayanan kesehatan wajib menyediakan fasilitas yang dibutuhkan dalam rangka penyelenggaran rekam medis (Permenkes RI, 2008). Fasilitas tersebut adalah media yang dibutuhkan dalam penyimpanan file rekam medis, seperti ruangan rekam medis yang memadai, rak penyimpanan yang besar, alat dan bahan yang dapat menunjang keutuhan serta melindungi rekam medis pasien. Dengan terpenuhinya hal tersebut terutama rak maka penyimpanan rekam medis dapat berjalan sesuai fungsinya. Selain itu berkas rekam medis menjadi lebih tertata rapi sehingga memudahkan dalam pengambilan rekam medis. Namun faktanya ruangan dan rak yang tersedia terbatas sehingga menjadi hambatan. Ruangan yang terbatas juga dapat menyebabkan terjadinya kesulitan dalam proses melayani dokumen rekam medis pasien. Hal ini sejalan dengan hasil penelitian sebelumnya bahwa kendala pelaksanaan retensi diberbagai fasilitas pelayanan kesehatan diakibatkan karena penyimpanan rak aktif dan inaktif dalam satu ruangan.

Berdasarkan hasil penelitian yang peneliti dapatkan mengenai adanya tinjauan pelaksanaan retensi berkas rekam medis maka peneliti berpendapat bahwa penambahan tempat penyimpanan rekam medis (filing) harus segera dilakukan supaya tidak ada lagi rekam medis yang disimpan didalam kardus karena tempat penyimpanan rekam medis tidak sesuai dengan jumlah berkas rekam medis yang setiap hari semakin bertambah banyak serta salah satu kelancaran dalam retensi ialah penyediaan alat-alat yang mumpuni untuk digunakan terkait pelaksanaan retensi dan pelaksanaan retensi tidak sesuai dengan prosedur yang telah ditetapkan dan petugas harus lebih teliti lagi terhadap berkas rekam medis yang akan diretensi dengan cara melihat tanggal terkahir pasien berobat dan petugas harus tahu lembar apa saja yang tidak boleh diretensi oleh petugas retensi.

\section{KESIMPULAN}

Pelaksanaan retensi di RS X ada 6 petugas yang bertanggung jawab terhadap pelaksanaan retensi setiap hari dan petugas berhasil menyelesaikan 50-100 berkas yang telah diretensi dengan jumlah per bulannya 1500 berkas rekam medis yang telah diretensi, Analisis Pelaksanaan Retensi Rekam Medis Guna Menghindari Penumpukan Rekam Medis Inaktif di RS X 
petugas bertanggung jawab atas pelaksanaan retensi dan petugas juga memiliki tugas pokok selain melaksanakan retensi berkas rekam medis. Petugas pelaksanaan retensi belum pernah mengikuti pelatihan atau kepala rekam medis sekalipun, hanya melakukan pengarahan di ruang filing. Dengan tidak adanya scanner di RS tersebut, tidak menutup kemungkinan terkendalanya proses retensi. Berdasarkan hasil penelitian yang peneliti dapatkan mengenai adanya tinjauan pelaksanaan retensi berkas rekam medis maka peneliti berpendapat bahwa penambahan tempat penyimpanan rekam medis(filing) harus segera dilakukan supaya tidak ada lagi rekam medis yang disimpan didalam kardus karena tempat penyimpanan rekam medis tidak sesuai dengan jumlah berkas rekam medis yang setiap hari semakin bertambah banyak serta salah satu kelancaran dalam retensi ialah penyediaan alat-alat yang mumpuni untuk digunakan terkait pelaksanaan retensi dan pelaksanaan retensi tidak sesuai dengan prosedur yang telah ditetapkan dan petugas harus lebih teliti lagi terhadap berkas rekam medis yang akan diretensi dengan cara melihat tanggal terkahir pasien berobat dan petugas harus tahu lembar apa saja yang tidak boleh diretensi oleh petugas retensi.

\section{BIBLIOGRAFI}

Apriliani, Eltigeka Devi, Muflihatin, Indah, \& Muna, Niyalatul. (2020). Analisis Pelaksanaan Retensi dan Pemusnahan Berkas Rekam Medis di Rumkital dr Ramelan Surabaya. J-REMI: Jurnal Rekam Medik Dan Informasi Kesehatan, 1(4), 564-574.

Betri, Evinia. (2020). Analisa Pelaksaan Retensi Dokumen Rekam Medis di RSU Muhammadiyah Ponorogo. Jurnal Delima Harapan, 7(2), 86-91.

Gunawan, Novi Indriyani, Nurseha, Meita, \& Hidayati, Meira. (2021). Analisis Retensi Rekam Medis Rawat Jalan Aktif ke Inaktif di UPT Puskesmas Sukarasa. Jurnal Ilmiah Perekam Dan Informasi Kesehatan Imelda (JIPIKI), 6(2), 131-138.

Indonesia, Konsil Kedokteran. (2006). Komunikasi efektif dokter-pasien. Jakarta: KKI.

Latuconsina, Nurfitria Dara, Dewi, Tiara Chandra, \& Susantyo, Andy. (2019). Tinjauan Pelaksanaan Retensi Sesuai Dengan Permenkes Ri No. 269 Tahun 2008 Dan Akreditasi Snars Di Rsud Kanjuruhan Kabupaten Malang. Kampurui Jurnal Kesehatan Masyarakat, 1(1), 11-16.

Menkes, R. I. (2013). Peraturan Menteri Kesehatan RI Nomor 55 Tahun 2013 tentang Penyelenggaraan Pekerjaan Rekam Medis. Jakarta: Indonesia.

Nomor, Permenkes Republik Indonesia. (2017). 269/Menkes/Per III 2008 tentang Rekam Medis.

Permenkes, R. I. (2014). No. 56 tahun 2014 tentang. Klasifikasi Dan Perizinan Rumah Sakit.

Permenkes RI. Peraturan Menteri Kesehatan Republik Indonesia Nomor 269 Tentang Rekam Medis. , (2008).

Ritonga, Zulham Andi, \& Wannara, Alan Juli. (2020). Faktor-faktor Penyebab Keterlambatan Waktu Penyediaan Rekam Medis Rawat Jalan di Rumah Sakit Umum Madani Tahun 2019. Jurnal Ilmiah Perekam Dan Informasi Kesehatan Imelda (JIPIKI), 5(1), 85-97.

Rustiyanto, Efile:///G:/ALL REFERENCE/rustiyanyo. risr., \& Rahayu, Warih Ambar. (2011). Manajemen Filing Dokumen Rekam Medis dan Informasi Kesehatan. Yogyakarta: Politeknik Kesehatan Permata Indonesia.

Salsabila, Auliya, Syahidin, Yuda, \& Hidayati, Meira. (2021). Perancangan Sistem Informasi Retensi Rekam Medis Berbasis Web di Rumah Sakit Umum Bina Sehat. Cerdika: Jurnal Ilmiah Indonesia, 1(10), 1271-1282.

Sugiyono. (2016). Metode Penelitian Kuantitatif, Kualitatif dan R\&D. Bandung: PT Alfabet.

Analisis Pelaksanaan Retensi Rekam Medis Guna Menghindari Penumpukan Rekam Medis Inaktif di RS X 
Wati, Oniek Mustika, \& Pujihastuti, Antik. (2011). Tinjauan Pelaksanaan Penyimpanan dan Penjajaran Dokumen Rekam Medis di Ruang Filing RSUD dr. Moewardi. Rekam Medis, 5(2).

Zulmi, Dwi Kurnia Lestari. (2016). Penerapan Komunikasi Pasien dan Keluarga Berdasarkan Standar Komisi Akreditasi Rumah Sakit (KARS) di Rumah Sakit Tk. II Pelamonia Makassar Tahun 2016. Universitas Islam Negeri Alauddin Makassar.

(C) 2021 by the authors. Submitted for possible open access publication under the (c) (7) (2) terms and conditions of the Creative Commons Attribution (CC BY SA) license (https://creativecommons.org/licenses/by-sa/4.0/). 